\title{
Immobilization of $\beta$-galactosidase from Aspergillus Oryzae on Macroporous PloyGMA Newly Prepared
}

\author{
Sufang Sun \\ College of Chemistry and Environmental Science, Hebei University \\ Baoding 071002, China \\ Lingyun Dong \\ College of Chemistry and Environmental Science, Hebei University \\ Baoding 071002, China \\ Xiaobing Xu \\ College of Chemistry and Environmental Science, Hebei University \\ Baoding 071002, China \\ Shigang Shen (Corresponding author) \\ College of Chemistry and Environmental Science, Hebei University \\ Baoding 071002, China
}

Tel: 86-0312-507-9359 E-mail: ssg@hbu.edu.cn

\begin{abstract}
The reactive, macroporous and massive epoxy group-containing polyGMA was synthesized simultaneously with methanol aqueous solution and nano-calcium carbonate as porogen by bulk copolymerization. After the polymer was smashed, particles with diameters in the range of 0.30 to $0.45 \mathrm{~mm}$ were taken as the carrier and the Scanning electron microscopy (SEM) micrographs were done to characterize its surface structure. Under the optimum conditions, $\beta$-galactosidase was immobilized on the supporter obtained above, the basic property and the kinetic data of all the immobilized enzyme were determined, and satisfactory results were obtained in enzyme activity, activity yield, $\mathrm{pH}$ stability, thermal stability, operational stability, and Michaelis constants $K_{\mathrm{m}}$. The conclusion obtained indicated that the ployGMA prepared concurrently with liquid and solid porogen was more suitable to immobilize enzyme than that purely with liquid solution as pore-forming agent.
\end{abstract}

Keywords: Glycidyl methacrylate, Nano-calcium carbonate, $\beta$-galactosidase, Immobilization, PolyGMA

\section{Introduction}

It is generally accepted that immobilization of enzymes is convenient for improving their performance as industrial biocatalysts. Immobilized proteins may permit recovery of the enzyme, simplify the design and performance of the reactor, etc. Hence the idea of immobilizing the enzyme on a rigid solid support has been of great industrial interest for many years (Katchalski-Katzir, E. 1993; Kennedy, J. F., Melo, E. H. M., \& Jumel, K. 1990; Klibanov, A. M. 1983; Rosevear, A. 1984).

There are many protocols for enzyme immobilization described in the literature, but most of them may be difficult to perform on an industrial scale, where long support handling may necessary and some dangerous substances cannot be utilized, problems that are not considered on a laboratory scale, where the experiment is performed by specialized staff under very controlled conditions.

Among all the materials used to immobilize enzyme, epoxy-activated carriers seem to be almost-ideal systems to develop very easy protocols for enzyme immobilization because epoxy group could exhibit good reactivity under mild conditions and would be very stable at neutral pH values even in wet conditions (Serio, Di. M., Maturo, C., Alteriis, De. 
E., Parascandola, P., Tesser, R., \& Santacesaria, E. 2003; Vaidya, B. K., Ingavle, G. C., Ponrathnam, S., Kulkarni, B. D., $\&$ Nene, S. N. 2008).

In hence, this kind of carriers could be stored for long periods of time and the reactions of epoxy groups in carriers with different nucleophilic groups on the protein surface (e.g., amino, hydroxy or thiol moieties) would be suitable to immobilize enzymes by forming extremely strong linkages (secondary amino bonds, ether bonds and thioether bonds) with minimal chemical modification of the protein (Mateo, C., Torres, R., Fern and ez-Lorente, G., Ortiz, C., Fuentes, M., \& Hidalgo, A., et al. 2008).

In this paper, the polyGMA with macroporous morphology, reactive epoxy groups was synthesized successfully by buck polymerization of glycidyl methacrylate (GMA) using N, N'-methylene-2-bis (acrylamide)(MBAA) as a crosslinking agent, a mixture of methanol aqueous solution as liquid pore-forming agents and nano-calcium carbonate as solid one. After the polymer was smashed, particles with diameters in the range of 0.30 to $0.45 \mathrm{~mm}$ were taken as the carrier and characterized by means of SEM method. Then the supporter obtained was employed to immobilize $\beta$-galactosidase from aspergillus oryzae, which efficiently catalyzes not only the hydrolysis of the $\beta$-galactoside linkages of lactose to glucose and galactose but also the transgalactosylation reaction to produce galactooligosaccharides (Mozaffar, Z., Nakanishi, K., Matsuno, R., \& Kamikubo, T. 1984)and the enzyme activity, the activity yield of the immobilized $\beta$-galactosidase was also investigated in order to examine the suitability of the supporter obtained from liquid and solid porogen to immobilize enzyme. Finally, the kinetic data of the immobilized enzyme, the values of Michaelis constants $K_{\mathrm{m}}$, was also determined.

\section{Experimental}

\subsection{Apparatus and Reagents}

Ultraviolet Spectrotometer (T6 New Century), Vacuum Desiccator (DZ-6020), Digital pH Meter (PHS-3C) and Water Constant Temperature Oscillator (SHA-B), Universal Grinder (FW-200) were used for the study. All the aqueous solutions were prepared by twice distilled water.

Glycidyl methacrylate (GMA) (99\%) was purchased from Shanghai Jinchao Chemical Co. Ltd. $\beta$-galactosidase from Aspergillus oryzae $(11.2 \mathrm{U} / \mathrm{mg})$ and o-nitrophenyl- $\beta$-D-galactopyranoside (ONPG) were obtained from Sigma. N, $\mathrm{N}^{\prime}$-methylene-2-bis (acrylamide) (MBAA), Azo-bis-isobutyronitrile (AIBN) and other reagents were all analytical grades.

\subsection{Preparation of Enzyme and Substrate Solution}

$0.1500 \mathrm{~g}$ of $\beta$-galactosidase was weighed and extracted in $25 \mathrm{~mL} 0.1 \mathrm{M}$ sodium phosphate buffer $(\mathrm{pH} 8.0)$. Then the enzyme solution was obtained and stored in the refrigerator for use.

The substrate solution was prepared by dissolving $0.0150 \mathrm{~g}$ ONPG in twice distilled water and made up $10 \mathrm{~mL}$ solution.

\subsection{Preparation of Macroporous Glycidyl Methacrylate Polymer}

The macroporous polyGMA was prepared by buck copolymerization in a reactor of plastic beaker. The reaction system contains a monomer mixture (GMA $1.4 \mathrm{~mL}$, MBAA $2.4000 \mathrm{~g}$ and acrylamide $0.7500 \mathrm{~g}$ ), initiator(AIBN $0.1 \%(\mathrm{w} / \mathrm{w}$ monomer)), $14 \mathrm{~mL}$ Methanol aqueous solution as liquid phase porogen( the ratio of inert component to monomer was $10: 1)$, and nano-calcium carbonate $(75 \% \mathrm{w} / \mathrm{w}$ monomer) as solid phase porogen. After the mixture was shaked up completely, the reaction was carried out at $70^{\circ} \mathrm{C}$. Then the large piece of solid obtained was smashed and the particles ranging from 0.30 to $0.45 \mathrm{~mm}$ were taken as the carrier. After being washed with water and ethanol completely, they were kept in acetone for $24 \mathrm{~h}$ to remove the liquid phase porogen and $0.1 \mathrm{M}$ hydrochloric acid solution for $24 \mathrm{~h}$ to get rid of nano-calcium carbonate, and then dried under vacuum. It is notable that, in the following discussion, the supporter only with liquid phase as porogen was called supporter I, and the one simultaneously with liquid and solid porogen was called supporter II .

\subsection{Method of immobilization}

The immobilization was carried out by adding an amount of polymer particles $(0.0500 \mathrm{~g})$ to $0.5 \mathrm{~mL} 0.1 \mathrm{M}$ phosphate buffer ( $\mathrm{pH} 8.0)$ containing enzyme $(6 \mathrm{mg} / \mathrm{mL})$. With gently stirring, the reaction was allowed to proceed at $25^{\circ} \mathrm{C}$. After 24 hours, the immobilized enzyme was filtered and washed with $0.1 \mathrm{M}$ phosphate buffer $(\mathrm{pH} \mathrm{5.0)}$ until no protein was detected. The enzyme bound on the supporter I was called the immobilized enzyme I, and that bound on the supporter II was called Immobilized Enzyme II .

\subsection{Enzyme activity assay}

The activity of the free enzyme and the immobilized enzyme were determined according to the references (Sun, S. F., Li, X. Y., \& Nu, S. L., et al. 1999; Tu, W. X., Sun, S. F., Nu, S. L., \& Li, X. Y. 1998) using ONPG as substrate. For the free enzyme activity, aliquots of it $(0.1 \mathrm{~mL})$ were added to $0.9 \mathrm{~mL} 0.1 \mathrm{M}$ phosphate buffer (pH 5.0). After being incubated at $55^{\circ} \mathrm{C}$ for $15 \mathrm{~min}$, the reaction was started by adding $0.2 \mathrm{~mL} 1.5 \mathrm{mg} / \mathrm{mL}$ ONPG. After being carried out for $2 \mathrm{~min}$ at $55^{\circ} \mathrm{C}$, 
the reaction was stopped by the addition of $2 \mathrm{~mL} 1 \mathrm{M} \mathrm{Na}_{2} \mathrm{CO}_{3}$ solution, and the amount of ONP was measured directly at $405 \mathrm{~nm}$. For the immobilized enzyme activity, $0.0500 \mathrm{~g}$ of the immobilized enzyme was soaked in $1 \mathrm{~mL} 0.1 \mathrm{M}$ phosphate buffer. The reaction was started by adding $0.2 \mathrm{~mL}$ ONPG $(1.5 \mathrm{mg} / \mathrm{mL})$. After being carried out for $2 \mathrm{~min}$ at $55^{\circ} \mathrm{C}$, the reaction was stopped and analyzed as above. The activity yield was calculated as the ratio of immobilized enzyme to enzyme subjected to immobilization. One unit of activity was defined as the amount of enzyme that liberated $1 \mu \mathrm{mol}$ of product $/ \mathrm{min}$ at $55^{\circ} \mathrm{C}$.

\subsection{Influence of Temperature and $\mathrm{pH}$}

The influence of the temperature on the galactosidase activity was determined using ONPG as substrate over the range of $40^{\circ} \mathrm{C}$ to $65^{\circ} \mathrm{C}$. Enzyme activity was determined after a long duration exposure to various temperature $\left(50^{\circ} \mathrm{C}, 60^{\circ} \mathrm{C}\right)$ followed by analysis at the $55^{\circ} \mathrm{C}$.

The $\mathrm{pH}$-activity curve in the range $3.0-10.0$ was determined for the free enzyme and the immobilized enzyme at $55^{\circ} \mathrm{C}$ using ONPG as substrate. The $\mathrm{pH}$ stability in the range 2.0-10.0 was determined after $30 \mathrm{~min}$ exposure to different $\mathrm{pH}$ at $55^{\circ} \mathrm{C}$.

\subsection{Kinetics}

The Michaelis constant $K_{\mathrm{m}}$ was calculated for the free and the immobilized enzyme by assaying the enzyme in increasing ONPG concentrations ranging from $0.25 \mathrm{mg} / \mathrm{mL}$ to $1.5 \mathrm{mg} / \mathrm{mL}$ in phosphate buffer.

\subsection{Operational stability of the immobilized enzyme}

The operational stability of the immobilized enzyme was determined according to the following procedures. $0.0500 \mathrm{~g}$ of the immobilized enzyme was taken and soaked in $1.8 \mathrm{~mL}$ phosphate buffer overnight. After the mixture was incubated at $55^{\circ} \mathrm{C}$ for $15 \mathrm{~min}$, the reaction was started by adding $0.2 \mathrm{~mL} 1.5 \mathrm{mg} / \mathrm{mL}$ ONPG and then the reactive mixture was analyzed as above. Afterward, the solid was filtered and washed thoroughly with distilled waster and the above experiment was repeated under the same conditions.

\section{Results and discussion}

\subsection{Comparison of supporter / and supporter //}

According to the conditions described above, the supporter I and the supporter II were obtained separately, and the Scanning electron micrographs of the dried polymer were obtained using KYKY-2800B scanning electron microscope. The results see Fig.1 and Fig.2. Scanning electron microscopy (SEM) micrographs showed that the supporter II, which simultaneously using methanol solution and nano-calcium carbonate as porogen, had a much more porous surface structure than that of the supporter I only with methanol solution as porogen. In addition, both supporters were used to immobilize enzyme under their optimum conditions, and the results obtained were listed in Table 1. From the results shown in Table 1, the activity of the immobilized enzyme on the supporter II reached a maximum of 519.66U/g dry carrier. The obtained enzyme activity was approximately four times values obtained on the supporter I, which could be explained that the porous surface properties of GMA polymer would favor higher adsorption capacity for the enzyme.

\subsection{Properties of the immobilized enzyme}

\subsection{1 $\mathrm{pH}$ Optima and $\mathrm{pH}$ stability}

Fig.3 Showed that the $\mathrm{pH}$ profile of the free enzyme peaked at $\mathrm{pH}$ 5.0. Similar $\mathrm{pH}$ was also found for the immobilized enzyme I and the immobilized enzyme II. The enzyme activity was determined by ONPG as substrate, at $55^{\circ} \mathrm{C}$ in various $\mathrm{pH}$ buffers (3.0-10.0) for $2 \mathrm{~min}$.

After all the enzymes were exposed to different $\mathrm{pH}(2.0-10.0)$ at $25^{\circ} \mathrm{C}$ overnight, enzyme activity was determined at $55^{\circ} \mathrm{C}$, pH 5.0 for all the enzyme for $2 \mathrm{~min}$, with ONPG as substrate. As shown in Fig.4, both the immobilized enzymes had a wider $\mathrm{pH}$ range than that of the free enzyme. In the range of 3.0-9.0, the immobilized enzyme activity remained $>95 \%$.

\subsubsection{Optimum Temperature and Thermostability}

As seen in Fig.5, just like that of the free enzyme, enzyme activity was determined by ONPG as substrate at various temperature $\left(40-65^{\circ} \mathrm{C}\right)$ at $\mathrm{pH} 5.0$ for $2 \mathrm{~min}$. The temperature optimum of both the immobilized enzymes was $55^{\circ} \mathrm{C}$.

Fig. 6 and Fig. 7 showed that the immobilized enzymes were more stable than the free enzyme. At $50^{\circ} \mathrm{C}$, after $8 \mathrm{~h}$, the remaining activity of the Immobilized enzyme I was $79 \%$, the immobilized enzyme II was $80.4 \%$, and the free enzyme was $59.9 \%$. At $60^{\circ} \mathrm{C}$, over a period of the same time, the residual activity of the free enzyme was $47.8 \%$, whereas that of the immobilized enzyme I was $62 \%$ and the immobilized enzyme II was $64.2 \%$. Results showed that both the immobilized enzymes had better thermostability than that of the free enzyme.

\subsubsection{Operational stability of the immobilized enzyme}

The experiment was repeated 8 times by using the procedures mentioned above with the same immobilized enzyme at 
the same initial concentration of ONPG. The results are summarized in Fig.8 and it was shown that the immobilized $\beta$-galactosidase I and the immobilized $\beta$-galactosidase II were used for 6 times without significant loss in activity, meaning that almost no enzyme was dissociated from the surface of the glycidyl methacrylate carrier in the course of the reaction, so the operational stability of the immobilized enzymes obtained was very good.

\subsubsection{Kinetic parameters}

Lineweaver-Burk plot for the free and the immobilized enzymes using ONPG as substrate was made and the values of $K_{\mathrm{m}}$ calculated from those graphs were shown in Table 2. From Table 2, it could be seen that the values of $K_{\mathrm{m}}$ for the immobilized enzymes were larger than that of the free enzyme, which was probably caused by the immobilization procedure and by the lower accessibility of the substrate to the active site of the immobilized enzyme (Arica, M. Y., Hasirc, V. 1993).

\section{Conclusion}

In this paper, the reactive, macroporous polyGMA was synthesized simultaneously with methanol aqueous solution and nano-calcium carbonate as porogenic agents by bulk copolymerization, and the particles with diameters in the range of 0.30 to $0.45 \mathrm{~mm}$ were taken as carrier after the polymer was smashed. Scanning electron microscopy (SEM) micrographs showed that the supporter II, which simultaneously using liquid and solid materials as porogen, had a much more porous surface structure than that of the supporter I only with liquid solution as porogen. Under the optimum conditions, $\beta$-galactosidase was immobilized on the supporter described above and the enzyme activity of the immobilized enzyme II was much higher than that of the immobilized enzyme I, which showed that the supporter II was more suitable to immobilize enzyme because of its increase in specific surface. Meanwhile properties of the free and both the immobilized enzymes were determined and compared, and satisfactory results of both the immobilized enzymes were obtained in $\mathrm{pH}$ stability, thermal stability and operational stability. Finally, $K_{\mathrm{m}}$ values for the free, the immobilized enzyme I and the immobilized enzyme II were obtained respectively. So it could be seen, the polymer as enzyme immobilization carrier, which usually was prepared with liquid solution as porogen by traditional method, could also be got well using solid and liquid materials as porogen, which was used to get more porous surface structure and more activated reaction group. It was useful for industrial application of polymer as enzyme immobilization carrier.

\section{References}

Arica, M. Y., \& Hasirci, V. (1993). International journal of technology and human interaction. J.Chem., 58, 287-290.

Katchalski-Katzir, E. (1993). Immobilized enzymes-Learning from past successes and failures. TIBTECH, 11, 471-478.

Kennedy, J. F., Melo, E. H. M., \& Jumel, K. (1990). Immobilized enzymes and cells. Chem. Eng. Prog., 45, 81-89.

Klibanov, A. M. (1983). Immobilized enzymes and cells as practical catalysts. Science, 219, 722-727.

Mateo, C., Torres, R., Fern and ez-Lorente, G., Ortiz, C., Fuentes, M., \& Hidalgo, A., et al. (2008). A New Tool for Improved Immobilization of Proteins by the Epoxy Method. Biomacromolecules, 4, 772-777.

Mozaffar, Z., Nakanishi, K., Matsuno, R., \& Kamikubo, T. (1984). Purification and properties of $\beta$-galactosidases from Bacillus circulans. Agric Biol Chem, 48, 3053-3061.

Rosevear, A. (1984). Immobilized biocatalysts-A critical review. J. Chem. Technol. Bioctechnol., 34B, 127-150.

Serio, Di. M., Maturo, C., Alteriis, De. E., Parascandola, P., Tesser, R., \& Santacesaria, E. (2003). Lactose hydrolysis by immobilized $\beta$-galactosidase: the effect of the supports and the kinetics Santacesaria. Catalysis Today, 79, 333.

Sun, S. F., Li, X. Y., \& Nu, S. L., et al. (1999). Immobilization and Characterization of $\beta$-Galactosidase from the Plant Gram Chicken Bean (Cicer arietinum). Evolution of Its Enzymatic Actions in the Hydrolysis of Lactose. J. Agric. Food Chemistry, 47, 819.

Tu, W. X., Sun, S. F., Nu, S. L., \& Li, X. Y. (1998). Immobilization of $\beta$-galactosidase from Cicer arietinum (gram chicken bean) and its catalytic actions. Food Chemistry, 64, 495-500.

Vaidya, B. K., Ingavle, G. C., Ponrathnam, S., Kulkarni, B. D., \& Nene, S. N. (2008). Immobilization of Candida rugosa lipase on poly (allyl glycidyl ether-co-ethylene glycol dimethacrylate) macroporous polymer particles. Bioresource Technology, 99, 3623.

Van der Geer, J., Hanraads, J. A. J., \& Lupton R. A. (2000). The art of writing a scientific article. Journal of Scientific Communications, 163, 51-59. 
Table 1.The immobilization results of $\beta$-galactosidase on the supporter I and the supporter II

\begin{tabular}{|c|c|c|}
\hline Type of supporter & $\begin{array}{c}\text { Immobilized enzyme activity } \\
\text { (U/g dry supporter) }\end{array}$ & Activity yield (\%) \\
\hline Supporter I & 144.55 & 21.51 \\
\hline Supporter II & 519.66 & 77.33 \\
\hline
\end{tabular}

Table 2. Kinetic parameters of immobilized enzyme I, II and free enzyme

\begin{tabular}{|c|c|c|c|}
\hline $\begin{array}{c}\text { Temperature }\left({ }^{\circ} \mathrm{C}\right) / \\
K_{\mathrm{m}}(\mathrm{mmol} / \mathrm{L})\end{array}$ & 40 & 50 & 60 \\
\hline $\begin{array}{c}\text { immobilized } \\
\text { enzyme I }\end{array}$ & 22.79 & 18.71 & 24.65 \\
\hline $\begin{array}{c}\text { immobilized } \\
\text { enzyme II }\end{array}$ & 20.65 & 15.56 & 19.53 \\
\hline free enzyme & 10.50 & 8.282 & 11.85 \\
\hline
\end{tabular}

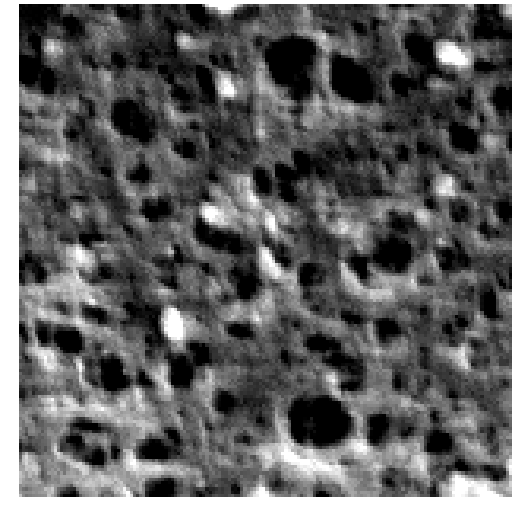

Figure 1. Supporter I

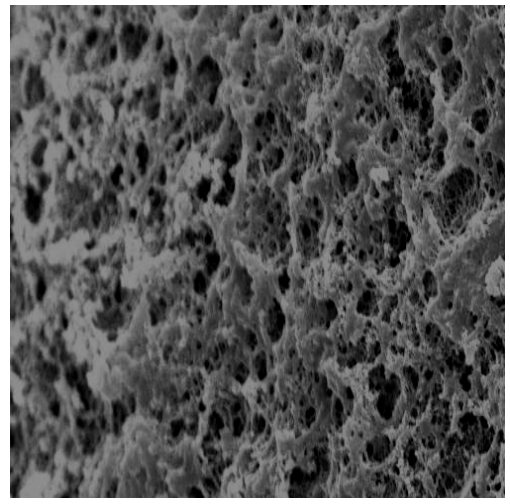

Figure 2. Supporter II 


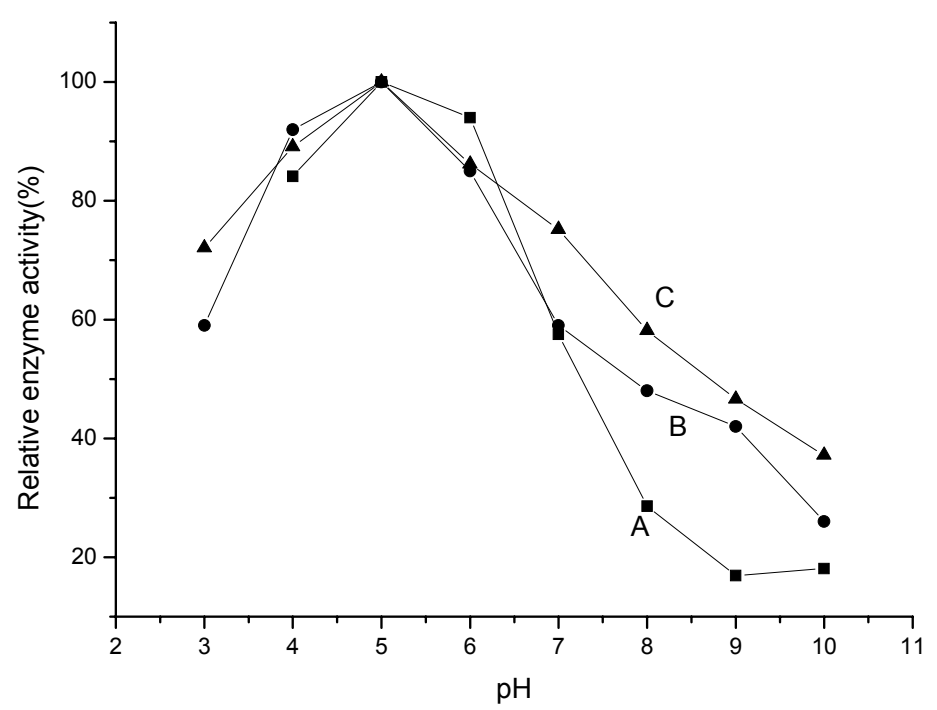

Figure 3. Influence of $\mathrm{pH}$ on the enzyme reaction

(A: Free enzyme; B: Immobilized enzyme I ; C: Immobilized enzyme II )

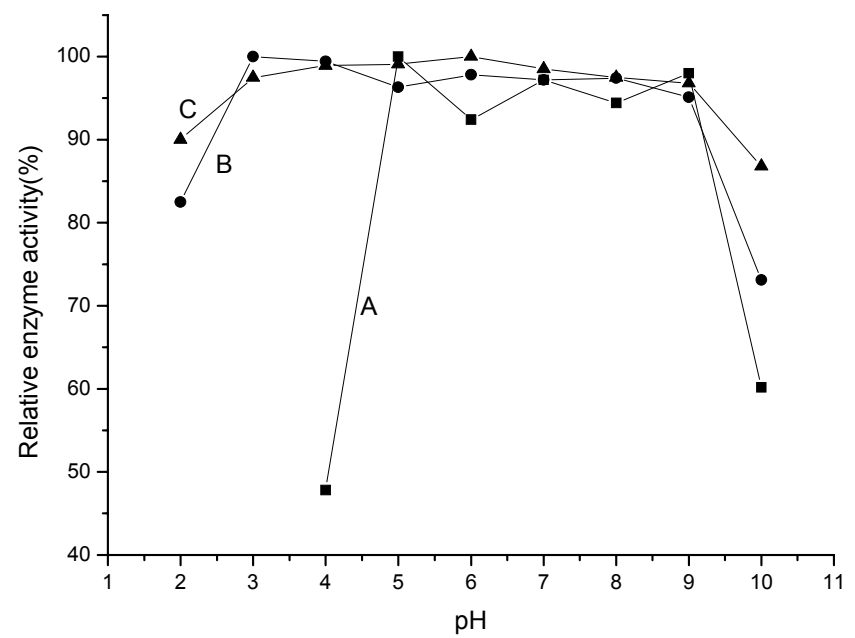

Figure 4. The $\mathrm{pH}$ stability of free enzyme and immobilized enzymes (A: Free enzyme; B: Immobilized enzyme I ; C: Immobilized enzyme II ) 


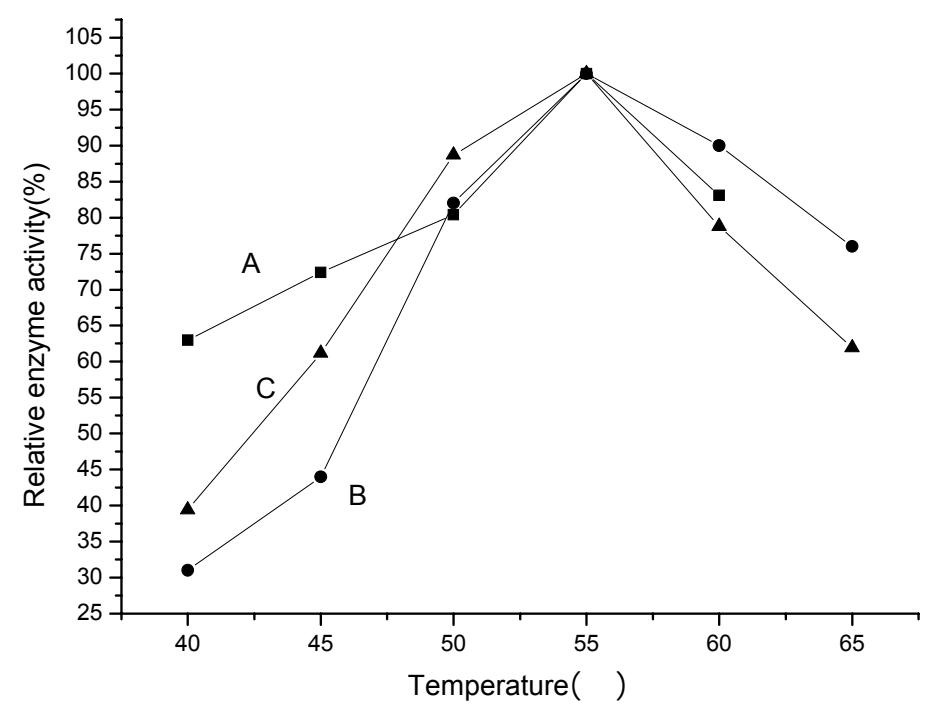

Figure 5. Influence of temperature on the enzyme reaction (A: Free enzyme; B: Immobilized enzyme I ; C: Immobilized enzyme II )

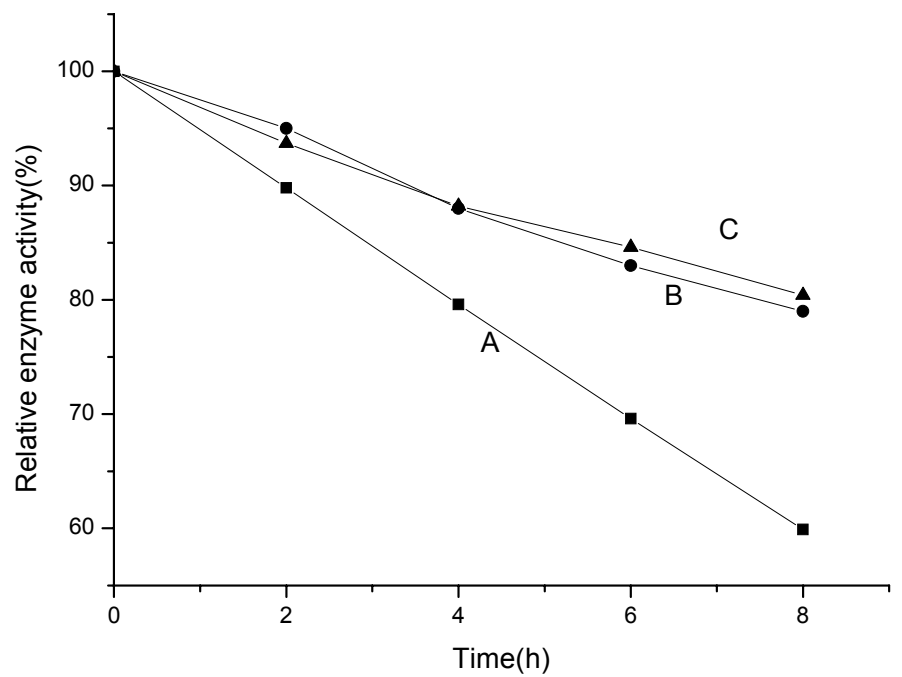

Figure 6 . Thermostability of different enzyme at $50^{\circ} \mathrm{C}$

(A: Free enzyme; B: Immobilized enzyme I ; C: Immobilized enzyme II ) 


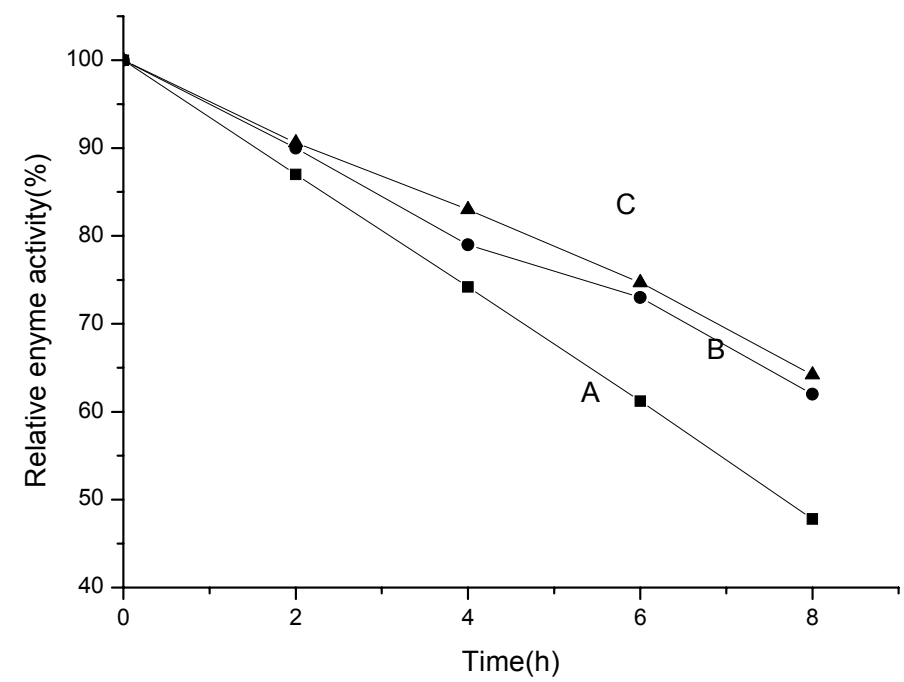

Figure 7. Thermostability of different enzyme at $60^{\circ} \mathrm{C}$

(A: Free enzyme; B: Immobilized enzyme I ; C: Immobilized enzyme II )

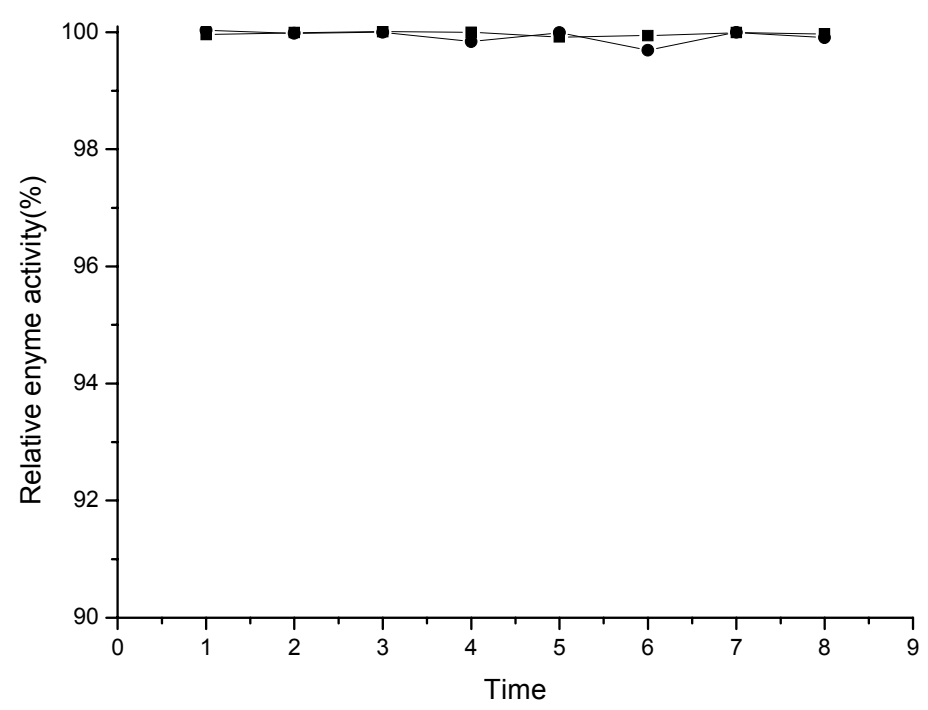

Figure 8. Operational stability 